\title{
Didymocyrtis epiphyscia (Phaeosphaeriaceae) is new to Kazakhstan and Central Asia
}

\author{
Andrei Tsurykau ${ }^{1,2} \&$ Ludmila Braginets ${ }^{3}$ \\ ${ }^{1}$ Department of Biology, Francisk Skorina Gomel State University, Sovetskaja Str. 104, BY-246019 Gomel, Belarus. \\ E-mail: tsurykau@gmail.com \\ ${ }^{2}$ Department of Ecology, Botany and Nature Protection, Institute of Natural Sciences, Samara National Research \\ University, Moskovskoye road 34, RU-443086 Samara, Russia \\ ${ }^{3}$ Department of Biology and Ecology, Kostanay State University named after A. Baitursynov, A. Baitursynov Str. 47, \\ KZ-110000 Kostanai, Kazakhstan. E-mail: labraginets@mail.ru
}

\begin{abstract}
Didymocyrtis epiphyscia s. lat. is reported for the first time for Kazakhstan and Central Asia. Anatomical characteristics of studied material are provided. Taxonomic difficulties of the D. epiphyscia complex are discussed. A possibly new lichenicolous Didymocyrtis species (on Parmelia sulcata) with non-guttulate conidia is described, illustrated and discussed.
\end{abstract}

Keywords: biodiversity, distribution, lichenicolous fungi, lichens, new records

\section{INTRODUCTION}

In Kazakhstan lichenicolous fungi were unexplored until very recently, when Hauck et al. (2013) and Zhurbenko \& Pino-Bodas (2017) reported two lichenicolous species, Abrothallus parmeliarum (Sommerf.) Arnold and Sphaerellothecium cladoniae (Alstrup \& Zhurb.) Hafellner, and one facultatively lichenicolous fungus, Athelia arachnoidea (Berk.) Jülich, from Altai and Tyan'-Shan' Mts in eastern Kazakhstan.

Recent fieldwork made by the second author in Kostanai district, northern part of the country, revealed two lichen specimens infected with coelomycetous lichenicolous fungi with ellipsoid hyaline non-septate conidia. Currently, lichenicolous Phoma-like species are considered to be polyphyletic and belong mainly to genera Abrothallus (Abrothallaceae), Briancoppinsia (Arthoniaceae), Didymocyrtis (Phaeosphaeriaceae), Phoma (Didymellaceae) and Xenophoma (Phaeosphaeriaceae) (Diederich et al., 2011; Lawrey et al., 2012; Trakunyingcharoen et al., 2014; Ertz et al., 2015; Wijayawardene et al., 2020). According to the type of conidiogenesis, shape and size of conidia, and host selection, the fungi were identified as belonging to Didymocyrtis, one of which appeared to be Didymocyrtis epiphyscia Ertz \& Diederich s. lat. The species has been known neither in Kazakhstan nor in Central Asia so far.

\section{MATERIAL AND METHODS}

Morphology and anatomy were studied using Nikon SMZ-745 and Nikon Eclipse 80i microscopes (Tokyo, Japan). Hand-made sections of pycnidia were studied in water. Measurements based on statistical data are indicated as (minimum-) X-SD-X+SD(-maximum), where $X$ represents the arithmetic mean and SD the corresponding standard deviation, followed by the number of measurements (n); the length breadth ratio is indicated as L/B and given in the same way, followed by the number of measurements (n).

\section{RESULTS AND DISCUSSION}

DiDYMOCYRTIS EPIPHYSCIA Ertz \& Diederich s. lat.

Conidiomata immersed in host thallus, black, up to $140 \mu \mathrm{m}$ in diameter. Conidiophores absent. Conidiogenous cells ampuliform, aseptate, hyaline, 3.5-6.5 $\mu \mathrm{m}$ in diameter. Conidia holoblastic, simple, hyaline, ellipsoid, with two small guttules, (4.5-)5.3-6.6(-7.5) × (2.0-)2.5-3.1(-3.5) $\mu \mathrm{m}, \mathrm{L} / \mathrm{B}$ ratio (1.5-) 1.9-2.4(-2.8), $\mathrm{n}=50$. The fungus is a strong pathogen, and the infected host tissues become pinkish or bleached (Fig. 1).

Notes. Ertz et al. (2015) segregated D. epiphyscia s. lat. on Physcia adscendens and P. tenella (thalli) from genetically related $D$. epiphyscia s. 

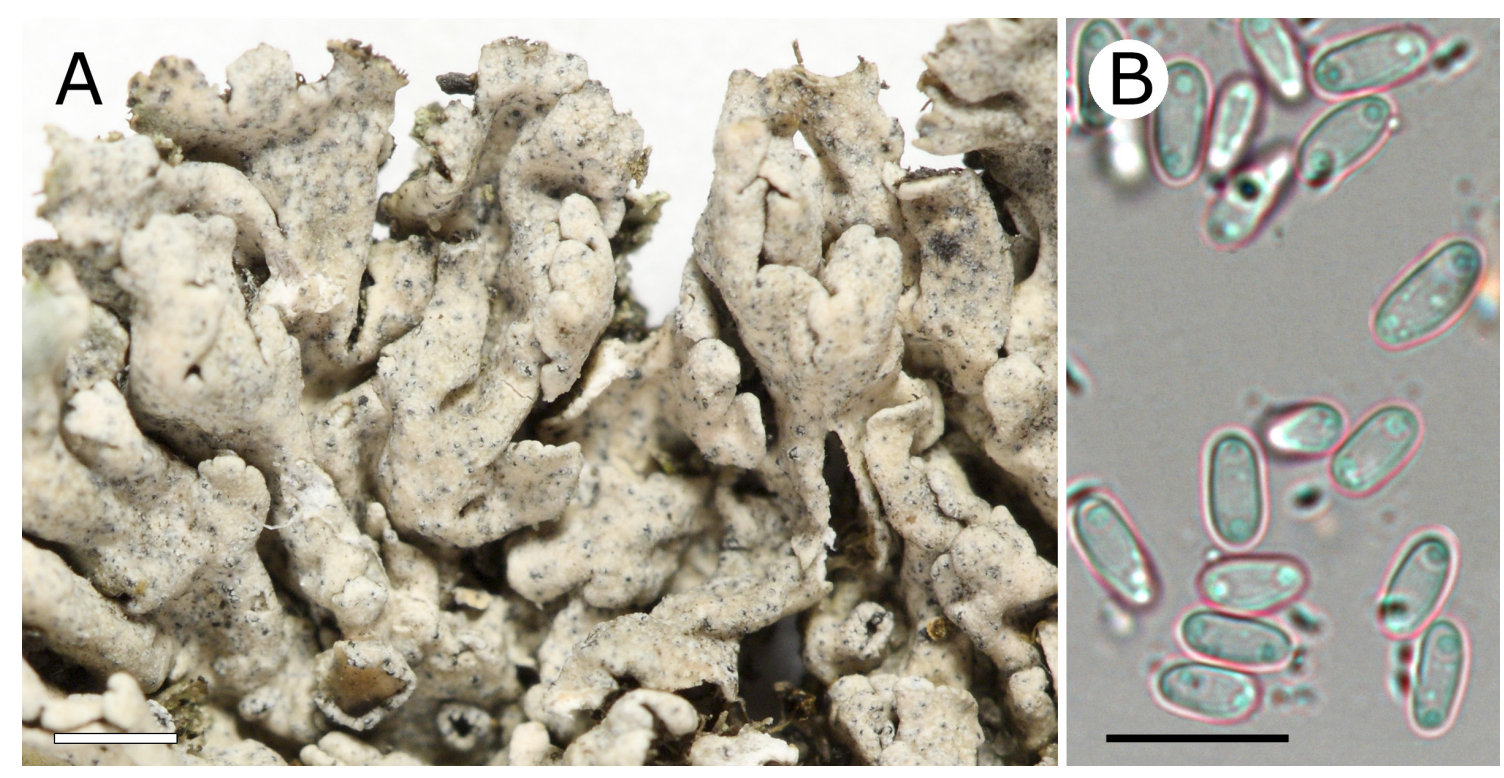

Fig. 1. Didymocyrtis epiphyscia s. lat. on Physcia aipolia (GSU): A - habitus, B - conidia. Scales: $\mathrm{A}=1 \mathrm{~mm}, \mathrm{~B}=10 \mu \mathrm{m}$.

str. on Physcia aipolia (mainly apothecia) based on constantly much narrower conidia, which are (3.7-)4.6-6.4(-8.0) × (2.0-)2.5-3.1(-3.5) $\mu \mathrm{m}$ in D. epiphyscia s. lat. and (4.0-)4.6-6.1(-7.8) $\times(3.2-) 3.5-4.2(-5.0) \mu \mathrm{m}$ in $D$. epiphyscia s. str. Our material perfectly matches the description of D. epiphyscia s. lat. except of the host species, Physcia aipolia.

Despite Ertz et al. (2015) considered material on Xanthoria parietina as belonging to $D$. epiphyscia due to genetical and morphological identity, the authors rejected previous reports of this fungus from other host genera, including Parmelia sulcata, as referring to other species (von Brackel, 2007, 2009; Zhurbenko et al., 2012). We found Phoma-like anamorphic fungus inhabiting Parmelia sulcata at nearby forest area in Kostanai district. Although its conidial dimensions [(4.5-) $5.2-6.5(-7.0) \times(2.0-) 2.6-3.6(-4.0) \mu \mathrm{m}, \mathrm{L} / \mathrm{B}$ ratio (1.4-)1.5-2.4(-2.9), $\mathrm{n}=20$ ] were quite similar to the conidial measures of our sample inhabiting Physcia aipolia, which was identified as Didymocyrtis epiphyscia, this specimen most probably is unrelated to $D$. epiphyscia due to the smaller pycnidia (50-80 $\mu \mathrm{m}$ in diameter), another type of host pathogenicity (brownish necrotic area vs. pinkish or bleached lobes) and absence of guttules (Fig. 2). Dimensional similarities of conidia are not unusual for members of Didymocyrtis. Following Diederich et al. (2007) and Ertz et al. (2015), D. cladoniicola has conidia 4.7-5.9 $\times 2.4-3.0 \mu \mathrm{m}, \mathrm{L} / \mathrm{B}$ ratio $1.7-2.2(\mathrm{n}=472)$, but it

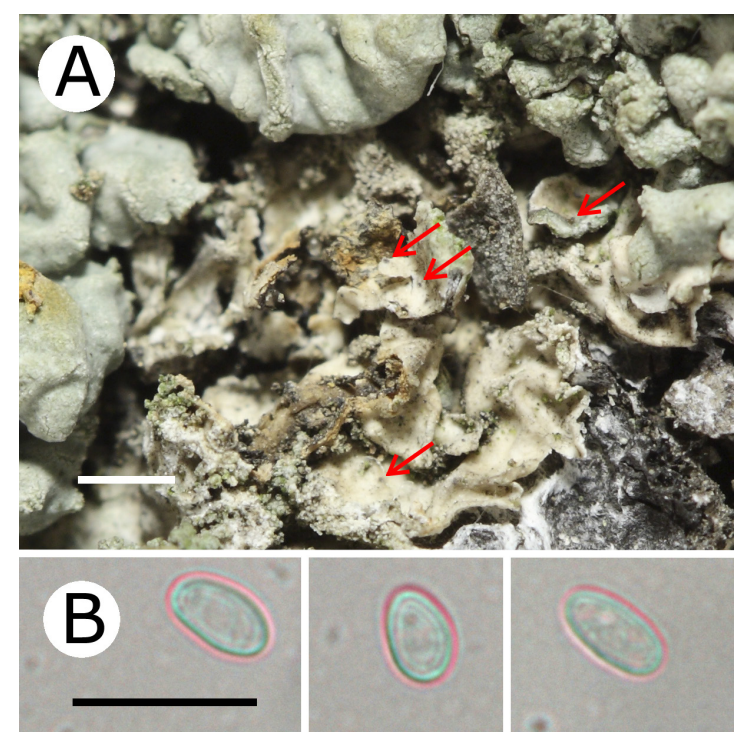

Fig. 2. Didymocyrtis sp. on Parmelia sulcata (GSU): A - habitus, red arrows indicate pycnidia, $\mathrm{B}-$ conidia. Scales: $\mathrm{A}=1 \mathrm{~mm}, \mathrm{~B}=10 \mu \mathrm{m}$. 
is genetically distinct from $D$. epiphyscia complex. We think that our specimen on Parmelia sulcata represents very likely an undescribed species but amount of material available does not allow us to make sufficient description. It is tentatively treated here as Didymocyrtis sp. until further studies.

Distribution. The worldwide distribution of Didymocyrtis epiphyscia is unclear due to the taxonomic difficulties (see Ertz et al., 2015). So far, D. epiphyscia s. lat. has been known from Europe (Belgium, France Germany, Italy and Luxembourg) (Ertz et al., 2015). In Asia the species was previously reported only from Khabarovsk Territory, Russia as Phoma physciicola Keissl. (Zhurbenko \& Tugi, 2013), however, this record may refer to another species due to unusual host selection. The reports of $P$. physciicola from Krasnoyarsk Territory and Chukotka Autonomous Area (Zhurbenko, 2009) most probably belong to $D$. epiphyscia s. str.

\section{Specimens examined.}

Didymocyrtis epiphyscia s. lat. Kazakhstan, Kostanai region, south of the city of Kostanai, "Zolotoy fazan" forest area, $53^{\circ} 09^{\prime} \mathrm{N}, 63^{\circ} 39^{\prime} \mathrm{E}$, pine forest, on Physcia aipolia (thallus) growing on wood, 04.04.2019, L. Braginets (GSU).

Didymocyrtis sp. Kazakhstan, Kostanai region, south of the city of Kostanai, "Zolotoy fazan" forest area, $53^{\circ} 09^{\prime} \mathrm{N}, 63^{\circ} 39^{\prime} \mathrm{E}$, pine forest, on Parmelia sulcata (thallus) growing on Pinus sylvestris, 04.04.2019, L. Braginets (GSU).

\section{ACKNOWLEDGEMENTS}

We thank Polina Papenko (Kostanai) for her help during the fieldwork. The anonymous reviewer and Tiina Randlane (Tartu) are warmly thanked for their valuable comments and suggestions.

\section{REFERENCES}

Diederich, P., Kocourková, J., Etayo, J. \& Zhurbenko, M. 2007. The lichenicolous Phoma species (coelomycetes) on Cladonia. Lichenologist 39: 153-163. https://doi.org/10.1017/S0024282907006044

Diederich, P., Lawrey, J. D., Sikaroodi, M., van den Boom, P. P. G. \& Ertz, D. 2012. Briancoppinsia, a new coelomycetous genus of Arthoniaceae (Arthoniales) for the lichenicolous Phoma cytospora, with a key to this and similar taxa. Fungal Diversity 52: 1-12. https://doi.org/10.1007/ s13225-011-0105-1
Ertz, D., Diederich, P., Lawrey, J. D., Berger, F., Freebury, C. E., Coppins, B., Gardiennet, A. \& Hafellner, J. 2015. Phylogenetic insights resolve Dacampiaceae (Pleosporales) as polyphyletic: Didymocyrtis (Pleosporales, Phaeosphaeriaceae) with Phoma-like anamorphs resurrected and segregated from Polycoccum (Trypetheliales, Polycoccaceae fam. nov.). Fungal Diversity 74: 53-89. https:/ / doi.org/10.1007/s 13225-015-0345-6

Hauck, M., Tønsberg, T., Mayrhofer, H. \& Breuss, O. 2013. Lichen-forming and lichenicolous fungi new to Kazakhstan. Herzogia 26: 103-116. https:// doi.org/10.13158/heia.26.1.2013.103

Lawrey, J. D., Diederich, P., Nelsen, M. P., Freebury, C., Van den Broeck, D., Sikaroodi, M. \& Ertz, D. 2012. Phylogenetic placement of lichenicolous Phoma species in the Phaeosphaeriaceae (Pleosporales, Dothideomycetes). Fungal Diversity 55: 195-213. https://doi.org/10.1007/s13225-012-0166-9

Trakunyingcharoen, T., Lombard, L., Groenewald, J. Z., Cheewangkoon, R., Toanun, C., Alfenas, A. C. \& Crous, P. W. 2014. Mycoparasitic species of Sphaerellopsis, and allied lichenicolous and other genera. IMA Fungus 5: 391-414. https:// doi.org/10.5598/imafungus.2014.05.02.05

von Brackel, W. 2007. Weitere Funde von flechtenbewohnenden Pilzen in Bayern. Beitrag zu einer Checkliste III. Berichte der Bayerischen Botanischen Gesellschaft 77: 5-26.

von Brackel, W. 2009. Weitere Funde von flechtenbewohnenden Pilzen in Bayern - Beitrage zu einer Checkliste IV. Berichte der Bayerischen Botanischen Gesellschaft 79: 5-55.

Wijayawardene, N. N. et al. 2020. Outline of fungi and fungi-like taxa. Mycosphere 11(1): (in press).

Zhurbenko, M. P. 2009. Lichenicolous fungi and lichens from the Holarctic. Part II. Opuscula Philolichenum 7: 121-186.

Zhurbenko, M. \& Pino-Bodas, R. 2017. A revision of lichenicolous fungi growing on Cladonia, mainly from the Northern Hemisphere, with a worldwide key to the known species. Opuscula Philolichenum 16: 188-266.

Zhurbenko, M. P. \& Tugi, E. W. 2013. Some noteworthy lichenicolous fungi from Khabarovsk Territory of Russia. Mycosphere 4(1): 46-51. https:/ / doi. org/10.5943/mycosphere/4/1/3

Zhurbenko, M. P., Hermansson, J. \& Pystina, T. N. 2012. Endococcus incrassatus new to Eurasia and some other lichenicolous fungi from the Komi Republic of Russia. Graphis Scripta 24: 36-39. 
Folia Cryptog. Estonica 